\title{
Crab Apple Blossoms as a Model for Research on Biological Control of Fire Blight
}

\author{
P. L. Pusey
}

U.S. Department of Agriculture, Agricultural Research Service, Tree Fruit Research Laboratory, 1104 N. Western Ave., Wenatchee, WA 98801. Accepted for publication 12 July 1997.

\begin{abstract}
Pusey, P. L. 1997. Crab apple blossoms as a model for research on biological control of fire blight. Phytopathology 87:1096-1102.

Nonseasonal availability of pomaceous flowers could improve laboratory detection and prefield testing of biocontrol agents for fire blight of pear and apple. Crab apple was selected as a model because of its high flower productivity on 1-year-old wood, high susceptibility to fire blight, and availability from nurseries. Cultivars Manchurian and Snowdrift were manipulated to bloom once by transferring dormant nursery trees from a cold room to a greenhouse and a second time by defoliating trees and applying $1 \%$ cytokinin and $0.1 \%$ gibberellins to the buds with a brush. Different sets of trees were induced at different times to bloom, so that flowers were produced 12 months in the year. When known bacterial antagonists (Erwinia herbicola strain C9-1 and Pseudomonas fluorescens

strain A506) were applied alone or in combination to the stigmas of detached crab apple blossoms prior to inoculation with the pathogen $(E$. amylovora strain Ea153), population interactions over time were comparable to those reported in previous studies involving pear or apple. In a subsequent series of experiments, the relative effects of 12 bacterial strains on stigmatic populations of strain Ea153 were similar for detached blossoms of crab apple in the laboratory, blossoms of intact crab apple trees in the greenhouse, and blossoms of pear and apple in the field. Additionally, when stigmas of detached crab apple blossoms were inoculated with antagonists (strains C9-1 and A506) and the pathogen, and later subjected to a 24-h wetting period, bacterial populations in the flower hypanthium increased and disease was suppressed. These studies indicate that crab apple blossoms can serve as a suitable model for year-round evaluation and study of biocontrol agents for fire blight.
\end{abstract}

Fire blight is a major constraint to pome fruit production in many areas of the world. It is most commonly initiated by epiphytic populations of Erwinia amylovora that develop on blossoms $(1,23)$. Under relatively dry climatic conditions, it is thought that bacterial colonization occurs predominantly on flower stigmas and that subsequent rain or heavy dew facilitates movement to the hypanthia, where infection generally occurs (22). Control programs have focused on the suppression of E. amylovora on floral parts through the use of antibiotics. However, pathogen resistance to streptomycin has developed in many production areas $(15,17)$, and the less effective antibiotic oxytetracycline has been substituted.

Microbial biocontrol of the blossom blight phase of fire blight has been demonstrated as an alternative to antibiotics $(4,5,11,13$, $24)$ or as a measure that could complement the use of antibiotics $(14,20)$. Recently, the product Blightban (a.i. Pseudomonas fluorescens strain A506; Plant Health Technologies, Boise, ID) became available commercially. Biocontrol as an approach to fire blight management holds added promise, given that relatively few of the numerous indigenous and epiphytic microorganisms found on pomaceous plants have ever been tested as biocontrol agents on flower tissue. The protocol to identify new biocontrol agents typically has involved screening putative antagonists of $E$. amylovora on artificial media $(2,23)$ or immature pear fruit $(3,7)$. Several variations of the pear fruit assay have been adopted, the latest refinement being described by Vanneste et al. (26). Wilson et al. $(28,29)$ found that the results of assays with fruit were sometimes inconsistent or did not correlate with biocontrol studies involving blossoms. However, Vanneste (24) pointed out that the fruit bioassay, if used as a qualitative rather than a quantitative measure,

Corresponding author: P. L. Pusey; E-mail address: pusey@tfrl.ars.usda.gov

Publication no. P-1997-0825-02R

This article is in the public domain and not copyrightable. It may be freely reprinted with customary crediting of the source. The American Phytopathological Society, 1997. effectively predicted the field performance of strains of E. herbicola. Although this method is simple and may be adequate for many studies, it does not perfectly model the manner in which biocontrol agents interact with E. amylovora on flowers (24). Investigations involving pomaceous flowers have generally been limited to the normal bloom period, which is relatively brief and occurs under field conditions that may or may not be conducive to fire blight development in a given year. Exceptions to this include work with dormant tree branches or potted plants that were periodically forced from cold dormancy $(30,31)$.

To accelerate research on biological control of fire blight, efforts were made to increase the nonseasonal availability of pomaceous flowers. If successful, this would permit the use of flowers for general screening and for in-depth studies under laboratory or controlled-environment conditions. Crab apple trees were selected as a source of flowers because of their high flower productivity on current season growth (apple and pear wood generally must be 2 years old before flowering), high susceptibility to fire blight, and availability from nurseries (as they are widely propagated and sold as pollinators for apple). The following investigation was conducted to demonstrate the feasibility of using crab apple blossoms for fire blight biocontrol studies and to evaluate the reliability of crab apple as a model for predicting the field performance of microbial antagonists against E. amylovora on pear and apple blossoms. A preliminary report of this work was previously published (18).

\section{MATERIALS AND METHODS}

Bacterial strains. Bacteria obtained from other workers were a nalidixic acid-resistant derivative of E. amylovora strain Ea153, rifampicin-resistant $P$. fluorescens strain A506, and a rifampicinresistant derivative of $E$. herbicola strain C9-1. Original strain codes, without letters previously added to indicate specific derivative types, are used in this report. Strain Ea153, obtained from K. Johnson, Oregon State University, Corvallis, was isolated from cankers on 'Gala' apple in Oregon and later used in biocontrol studies 
in the field $(10,11,20)$. Strain A506, originally from S. Lindow, University of California, Berkeley, was isolated from pear in California and reduced fire blight incidence $(11,13,14,25)$. Strain C9-1, originally from C. Ishimaru, Colorado State University, Fort Collins, was isolated from 'Jonathan' apple fruit in Michigan and produced at least two antibiotics, herbicolins $\mathrm{O}$ and $\mathrm{I}$, that are inhibitory to E. amylovora (9). The rifampicin-resistant derivative of C9-1 mixed with A506 reduced fire blight of pear (11).

Ten other bacteria used were isolated from apple blossoms near Wenatchee, WA, in 1994, and together these represented a range of biocontrol activities based upon preliminary laboratory assays with detached crab apple blossoms. Rifampicin-resistant derivatives were generated spontaneously from each of the 10 strains for use in this study. Identifications were made based on fatty acid methyl ester analysis of whole cell fatty acids using gas chromatography and profile analysis with Microbial Identification System software (Microbial ID, Inc., Newark, DE). The bacteria were identified as Arthrobacter protophormiae (strain E424), Bacillus pumilus (strain E185), Curtobacterium flaccumfaciens (strain E16), E. herbicola (strain E325), P. chlororaphis (strain E326), P. cichorii (strain E173), P. fluorescens (strain E166), P. marginalis (strain E154), $P$. putida (strain E300), and $P$. syringae (strain E12).

Crab apple trees. 'Manchurian' and 'Snowdrift' crab apple trees (16-mm minimum diameter on M.9 or M.26 rootstock) were obtained from Cameron Nursery (Eltopia, WA), Columbia Basin Nursery (Quincy, WA), and Van Well Nursery (Wenatchee, WA). From January until June or July of each year, dormant trees were transferred weekly by groups from a cold room $\left(1\right.$ to $\left.2^{\circ} \mathrm{C}\right)$ to a greenhouse, where they were forced to bloom. Trees were held in the cold room from 0 to 5 months following acquisition from the nursery. After a growth period of about 5 months, but with no cold dormancy, trees were induced to flower a second time. For each tree, leaves were manually removed, and a solution of $1 \%$ cytokinin ( $N$-(phenylmethyl)-1H-purine 6-amine) and $0.1 \%$ gibberellins $\mathrm{A}_{4} \mathrm{~A}_{7}$ (active ingredients in Accel; Abbott Laboratories, North Chicago, IL) was brushed once onto the buds. On a weekly basis, tree groups were treated in the same order as above, from June or July until the following January or February. Bloom occurred 2 to 3 weeks after the transfer of trees from the cold room (first bloom) or the application of growth regulators (second bloom). The above procedures resulted in the continual availability of flowers for year-round studies in the laboratory and greenhouse.

Bacterial interactions on detached blossoms over time. 'Manchurian' crab apple flowers of similar age were obtained by stripping one or more greenhouse trees of all open flowers on one day, and then collecting newly opened flowers on the following day. Each detached flower was maintained with the cut peduncle submerged in $25 \%$ sucrose solution in a single vial, and vials were supported in plastic tube racks. The sucrose concentration used was based on preliminary trials indicating that flowers enclosed in plastic containers maintained a healthy appearing state the longest (stigmas still green and petals retained for 5 to 6 days) when sucrose levels in the holding vials were at 20 or $25 \%$. Bacteria were cultured on nutrient yeast dextrose agar (nutrient broth, $8 \mathrm{~g}$; yeast, $5 \mathrm{~g}$; dextrose, $5 \mathrm{~g}$; agar, $15 \mathrm{~g}$; and deionized water, 1 liter) for $24 \mathrm{~h} \mathrm{at}$ $24^{\circ} \mathrm{C}$, and cell suspensions were prepared in $10 \mathrm{mM}$ potassium phosphate buffer (pH 7.0) and 0.03\% Tween-20. Strains A506 and C9-1, suspended at $10^{8} \mathrm{CFU} / \mathrm{ml}$, were applied alone or in combination (1:1 mix; thus, the concentration of each strain was diluted by one half) to flowers by touching a droplet of the suspension to each stigma to form a thin film of moisture $(0.1$ to $0.2 \mu \mathrm{l}$ per flower). Flowers were allowed to air-dry in a laminar flow hood, and then were enclosed in 4-liter plastic containers (Rubbermaid, Twinsburg, $\mathrm{OH}$ ) and incubated at $24^{\circ} \mathrm{C}$. No water, other than that in the sucrose solution in vials, was added to the containers. Relative humidity was measured at 60 to $65 \%$ using a hand-held meter with a probe that was inserted through a small hole in each container. After $24 \mathrm{~h}$, strain Ea153 was suspended at $10^{7} \mathrm{CFU} / \mathrm{ml}$ and similarly applied to the flowers. Control flowers were treated with Ea153 at $10^{7} \mathrm{CFU} / \mathrm{ml}$. Ea153 also was applied to untreated flowers at $10^{8} \mathrm{CFU} / \mathrm{ml}$ in order to compare stigma colonization by Ea153 with that of the antagonists applied at the same concentration. At intervals of 12 or $24 \mathrm{~h}$ of incubation, 10 flowers per treatment were sampled to determine bacterial population sizes. The stigma and a portion of the supporting style were placed in sterile microcentrifuge tubes containing $1 \mathrm{ml}$ of sterile buffer $(10 \mathrm{mM}$ potassium phosphate, $\mathrm{pH}$ 7.0). Tubes were vortexed briefly and placed in a sonication bath (Braun model 3200; Bronson Cleaning Equipment Co., Shelton, CT) for $60 \mathrm{~s}$. Samples were again vortexed, and serial dilutions were spread on selective media. CCT medium (defined by Ishimaru and Klos [8]) amended with nalidixic acid $(50 \mu \mathrm{g} / \mathrm{ml})$ was used for detection of Ea153, and Kings medium B (12) amended with rifampicin $(25 \mu \mathrm{g} / \mathrm{ml})$ and cycloheximide $(50$ $\mu \mathrm{g} / \mathrm{ml}$ ) was used for detection of A506 and C9-1. After 3 to 4 days of incubation at $24^{\circ} \mathrm{C}$, bacterial colonies were counted. The test was conducted twice.

Crab apple blossoms versus blossoms of field-grown pear and apple. All 12 bacterial strains listed above were tested against strain Ea153 on detached blossoms of 'Manchurian' and 'Snowdrift' crab apple in the laboratory, on blossoms of intact trees of both crab apple cultivars in the greenhouse, and on blossoms of 'Bartlett' pear and 'Gala' apple trees in the field. Procedures were the same as those described above for detached blossoms in the laboratory, with the following exceptions. In the greenhouse and field, unopened flowers in the "popcorn" stage of development were tagged on one day and treated with test bacteria on the following day when the flowers were open. Suspensions of the test bacteria $\left(10^{8} \mathrm{CFU} / \mathrm{ml}\right)$ and the pathogen $\left(10^{7} \mathrm{CFU} / \mathrm{ml}\right)$ were applied with a pipette by dispensing $0.5 \mu \mathrm{l}$ of suspension to the stigma. Detached blossoms were allowed to dry in a laminar flow hood as before, but no effort was made to accelerate drying in the greenhouse or field. In the greenhouse, where the average daily maximum and minimum temperatures were 30.0 and $20.5^{\circ} \mathrm{C}$, inoculations and determination of bacterial populations were done according to the same schedule given for laboratory assays. In the field, however, temperatures were lower (the daily maximum ranged from 12.2 to $22.3^{\circ} \mathrm{C}$ and the daily minimum ranged from -1.4 to $8.2^{\circ} \mathrm{C}$ ), and so more time was allowed for bacterial colonization. The time interval between application of the test bacteria and the pathogen was $48 \mathrm{~h}$ for pear and $24 \mathrm{~h}$ for apple; the time interval between inoculation with the pathogen and collection of flowers for population determination was $48 \mathrm{~h}$ for both pear and apple. Greenhouse and field samples were processed immediately after collection to determine microbial population sizes on the stigmas. Populations of E. amylovora were determined as described above, and those of the test bacteria were determined on Kings medium B amended with rifampicin $(25 \mu \mathrm{g} / \mathrm{ml})$ and cycloheximide $(50 \mu \mathrm{g} / \mathrm{ml})$.

For each cultivar and test environment, 10 trees were used. Each bacterial strain was applied to one flower per tree. In the laboratory, flowers from a single tree were grouped together, forming a randomized complete block design (two replicates per each of five plastic containers). In the greenhouse and field, suitable flowers were selected at scattered sites on the tree, and treatments applied were determined randomly. All tests were conducted twice. The two field trials with pear were initiated on 18 and 20 April 1995; those involving apple were begun on 25 and 26 April 1995.

Effect of antagonists on disease development in detached blossoms. Detached blossoms of 'Manchurian' crab apple were maintained as described above, except that flowers were placed in $10 \%$ sucrose. The sucrose concentration was adjusted downward from the $25 \%$ level used previously, because it was discovered that lower concentrations were required for infection to occur. As above, flowers were treated with A506 or C9-1 and then, $24 \mathrm{~h}$ later, inoculated with Ea153. At $24 \mathrm{~h}$ after inoculation with strain Ea153, flowers were wetted by applying $10 \mu \mathrm{l}$ of buffer $(10 \mathrm{mM}$ potassium phosphate, $\mathrm{pH} 7.0$, and $0.1 \%$ Tween-20) over the stigma, 
allowing the excess to flow downward to the hypanthium. For the next $24 \mathrm{~h}$, flowers were incubated at $24^{\circ} \mathrm{C}$ and a relative humidity of approximately $100 \%$, achieved by placing paper towels in the bottoms of containers and saturating them with water. Afterwards, flowers were allowed to air-dry, wet paper towels were removed, and incubation was continued at approximately 60 to $65 \%$ relative humidity. Bacterial populations on the stigma and the hypanthium were determined using the above methods; as described for the stigma, the hypanthium was separated from other flower parts and washed in buffer. This was done by sampling five flowers per treatment just before the start of the wetting period ( $24 \mathrm{~h}$ after inoculation with Ea153) and again by sampling another five flowers $24 \mathrm{~h}$ after the wetting
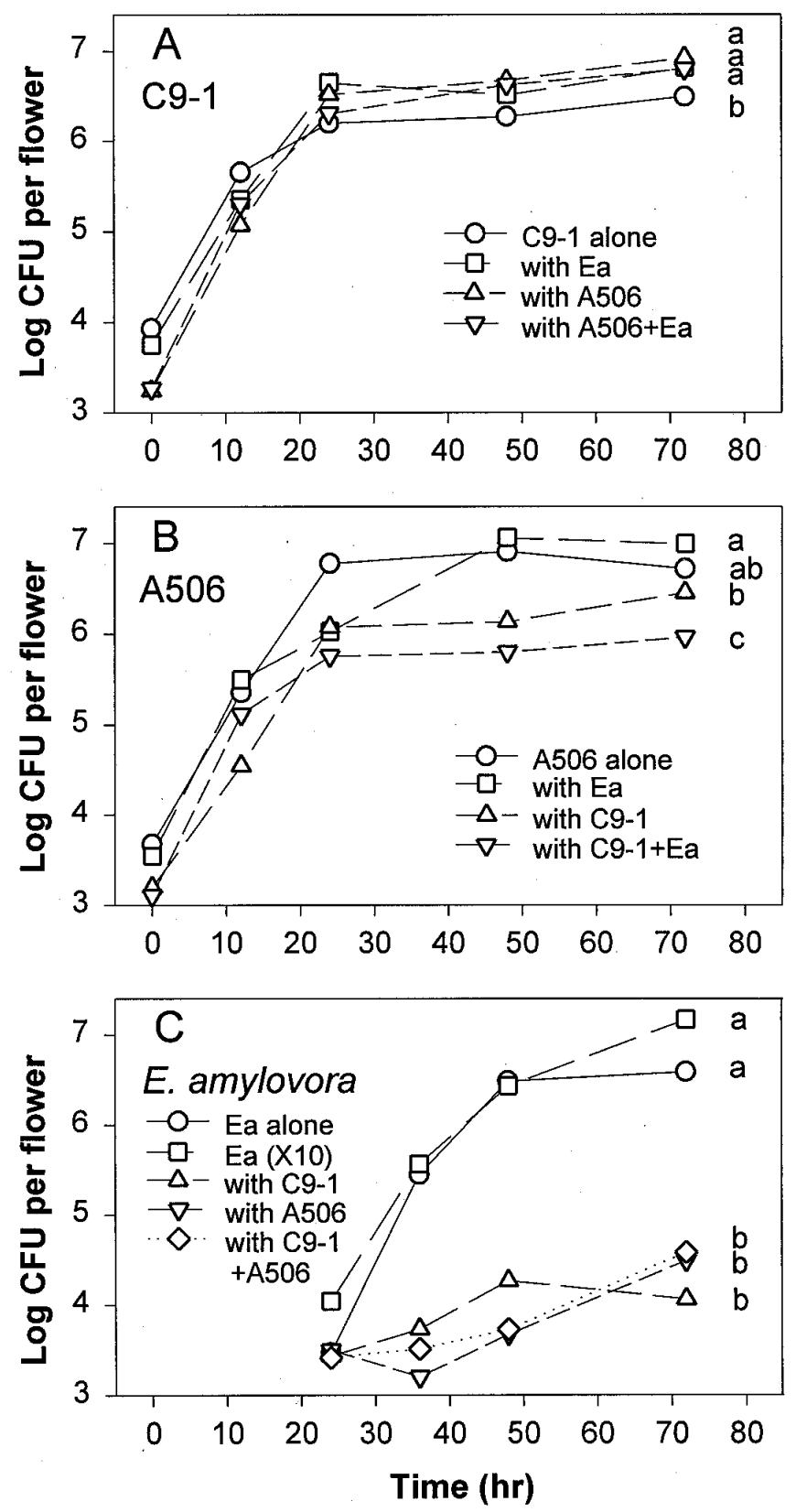

Fig. 1. Interaction of Erwinia herbicola (C9-1), Pseudomonas fluorescens (A506), and E. amylovora (Ea) on stigmas of detached blossoms of 'Manchurian' crab apple. Mean population sizes per flower are presented for A, C9-1; B, A506; and C, E. amylovora for each treatment combination. Antagonists were applied alone or in combination $\left(10^{8} \mathrm{CFU} / \mathrm{ml}\right) 24 \mathrm{~h}$ prior to inoculation or no inoculation with E. amylovora $\left(10^{7} \mathrm{CFU} / \mathrm{ml}\right) ;$ E. amylovora also was applied at $10^{7} \mathrm{CFU} / \mathrm{ml}\left(\right.$ Ea alone) or $10^{8} \mathrm{CFU} / \mathrm{ml}(\times 10)$ to flowers not treated with antagonists. At $72 \mathrm{~h}$, means with the same letter were not different according to the least significant difference test $(P \leq 0.05)$. period (or $72 \mathrm{~h}$ after inoculation with Ea153). At 7 or 8 days after inoculation, 20 flowers were rated for disease development using a 0 to 4 scale $(0=$ no necrosis; $1=$ detectable necrosis; $2=$ up to one-half of ovary necrotic; 3 = between one-half and whole ovary necrotic; and $4=$ necrosis extending below ovary). The test was conducted twice.

Statistical analyses. All data were analyzed using SAS (Statistical Analysis Systems Institute, Cary, NC) analysis of variance (ANOVA) and means were separated according to the least significant difference test (LSD) $(P \leq 0.05)$. Preliminary trials with a minimum of 150 flowers, treated with strains A506 and Ea153, indicated that estimates of bacterial population sizes did not fit either the log-normal or the normal distribution. In tests involving only the antagonists A506 and C9-1, log-transformed data from two trials were tested for homogeneity according to Hartley's $F$ max test and pooled for ANOVA. In the series of tests involving 12 different test bacteria, the pooled data were not transformed, but were analyzed and graphically presented in the arithmetic form, because this approach resulted in a ranking of test bacteria that was most consistent and easiest to discern. Variability in tests with the 12 bacteria was high, particularly in the field. If the highest value for a given treatment was 10 times greater than the next highest value, or the lowest value was 10 times lower than the next lowest value, it was treated as an outlier and omitted. The limit of detection in dilution plate assays was $100 \mathrm{CFU}$. A 0 value was omitted as an outlier only when the next lowest value was equal to or greater than 1,000 .

\section{RESULTS}

Bacterial interactions on detached blossoms over time. When strain C9-1, A506, or Ea153 was applied to flower stigmas and incubated at $24^{\circ} \mathrm{C}$ under laboratory conditions, populations increased exponentially during the initial $24 \mathrm{~h}$ and, thereafter, remained relatively constant (Fig. 1). Maximum populations for each bacterial strain per flower were generally between $10^{6}$ and $10^{7}$ CFU. Some of the differences indicated below may have resulted because the inoculum dose of each antagonist in the combination treatments was one half that of the antagonist applied alone. At 0 and $12 \mathrm{~h}$ after inoculation, the population sizes of C9-1 applied alone were greater $(P \leq 0.05)$ than those of $C 9-1$ in the presence of A506; but, at $24 \mathrm{~h}$ and longer, population sizes of C9-1 were lower than those of $\mathrm{C} 9-1$ in the presence of A506 (Fig. 1A). Population sizes of C9-1 were greater in the presence of Ea153 after $72 \mathrm{~h}$, but not at $48 \mathrm{~h}$. From 0 to $48 \mathrm{~h}$, population sizes of A506 alone were greater than those of A506 in the presence of C9-1; at $72 \mathrm{~h}$, the population size of A506 alone was not statistically greater than that with $\mathrm{C} 9-1$, but was greater compared with that with C9-1 plus Ea153 (Fig. 1B). Based on treatments involving only A506 and Ea153, A506 populations at 48 and $72 \mathrm{~h}$ were not affected by Ea153. Flowers inoculated with Ea153 at $10^{8}$ $\mathrm{CFU} / \mathrm{ml}$ had larger Ea153 population sizes initially $(P \leq 0.05)$ than those treated with Ea153 at $10^{7} \mathrm{CFU} / \mathrm{ml}$, but this difference was not evident in later sampling dates (Fig. 1C). From $36 \mathrm{~h}$ (or $12 \mathrm{~h}$ after inoculation with Ea153) to $72 \mathrm{~h}$, population sizes of Ea153 were reduced dramatically by C9-1 alone, A506 alone, or a mixture of the two. At $36 \mathrm{~h}$, the reduction of the Ea153 population caused by A506 was significantly greater $(P \leq 0.05)$ than that caused by C9-1. After $36 \mathrm{~h}$, treatments with C9-1, A506, or the mixture did not differ in their effect on Ea153. An overall comparison of treatments, according to linear regression analysis $(P \leq$ 0.05 ) of data in Figure 1A and B, was similar to that shown for $72 \mathrm{~h}$, based on the LSD. Lines in Figure 1C could not be compared, because the quadratic times treatment interaction was different.

Crab apple blossoms versus blossoms of field-grown pear and apple. In evaluations involving blossoms of two crab apple cultivars in the laboratory and greenhouse, and blossoms of pear and apple in the field, the ranking and relative ability of 12 bacterial strains to suppress growth of strain Ea153 on stigmas was 
always similar, regardless of flower type and environment (Fig. 2). Mean population sizes of Ea153 for control flowers in these tests ranged from $1.2 \times 10^{6}$ to $5.0 \times 10^{6} \mathrm{CFU}$ per flower. For each test, Ea153 population sizes resulting from treatment with the 12 test strains are presented from lowest to highest (Fig. 2). In every case, treatment with strain E325 resulted in the greatest suppression of Ea153. C9-1 and A506 were always among the most suppressive strains. Strains E300 and E326, which were among the top five antagonists on pear and apple blossoms, were always ranked at least among the top seven in tests involving crab apple blossoms.
The highest ranked strains generally were different from the control $(P \leq 0.05)$, but not from each other. Bacterial strains that had the greatest effect on Ea153 tended to be among those with the largest population sizes (Fig. 3); mean population sizes for E325, C9-1, A506, and E300 ranged from $2.1 \times 10^{6}$ to $1.3 \times 10^{7}$ CFU per flower in the different tests. Although E326 was often among strains most antagonistic to Ea153, it usually was undetected or found in low numbers. It was later discovered, however, that E326 had an unstable resistance to rifampicin, as it sometimes grew poorly, or not at all, on rifampicin-amended media.
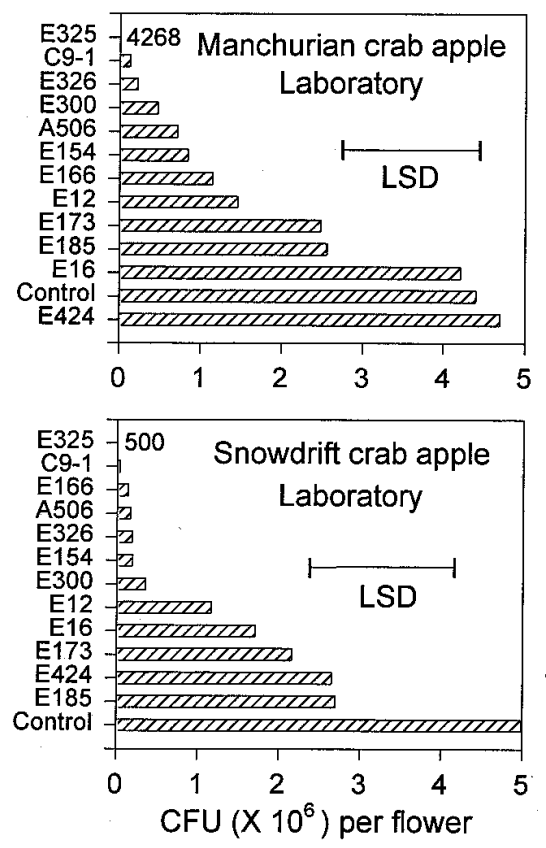
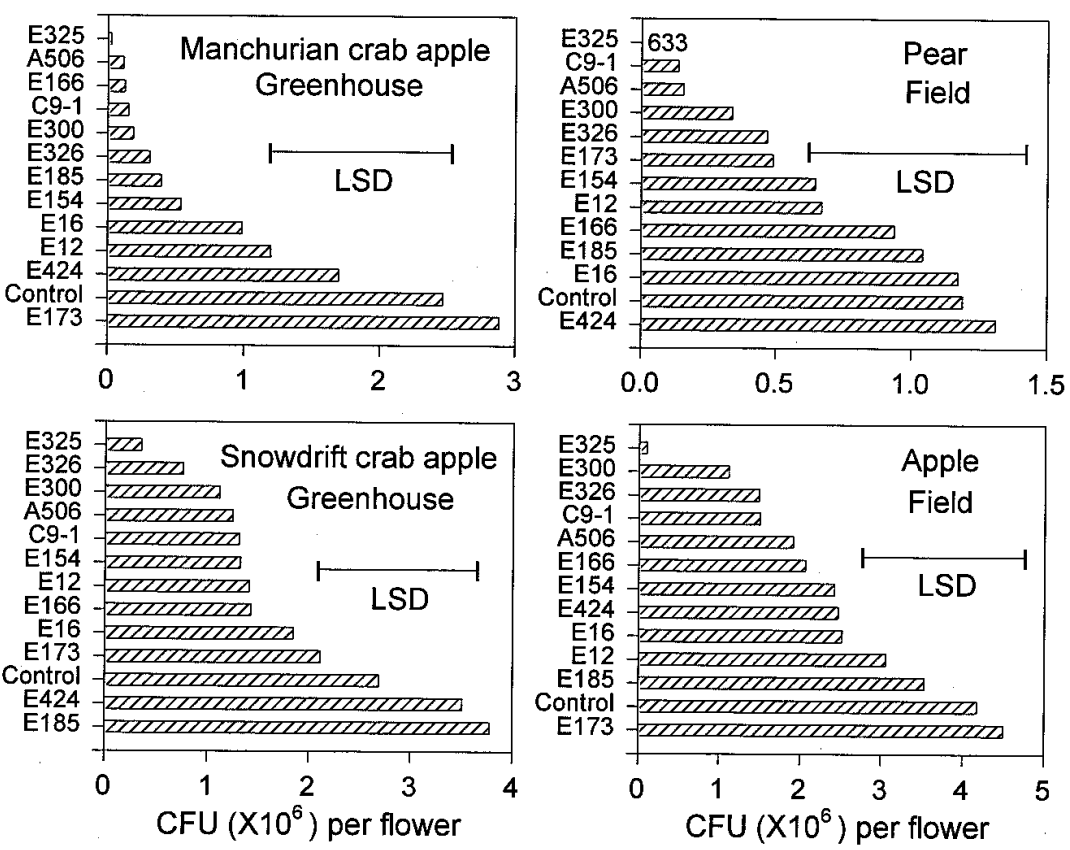

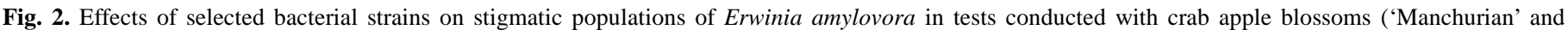

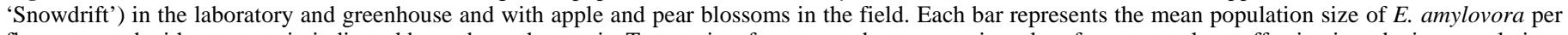

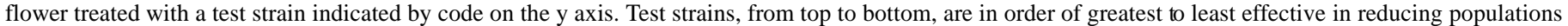
of E. amylovora. Line indicates least significant difference at $P \leq 0.05$.
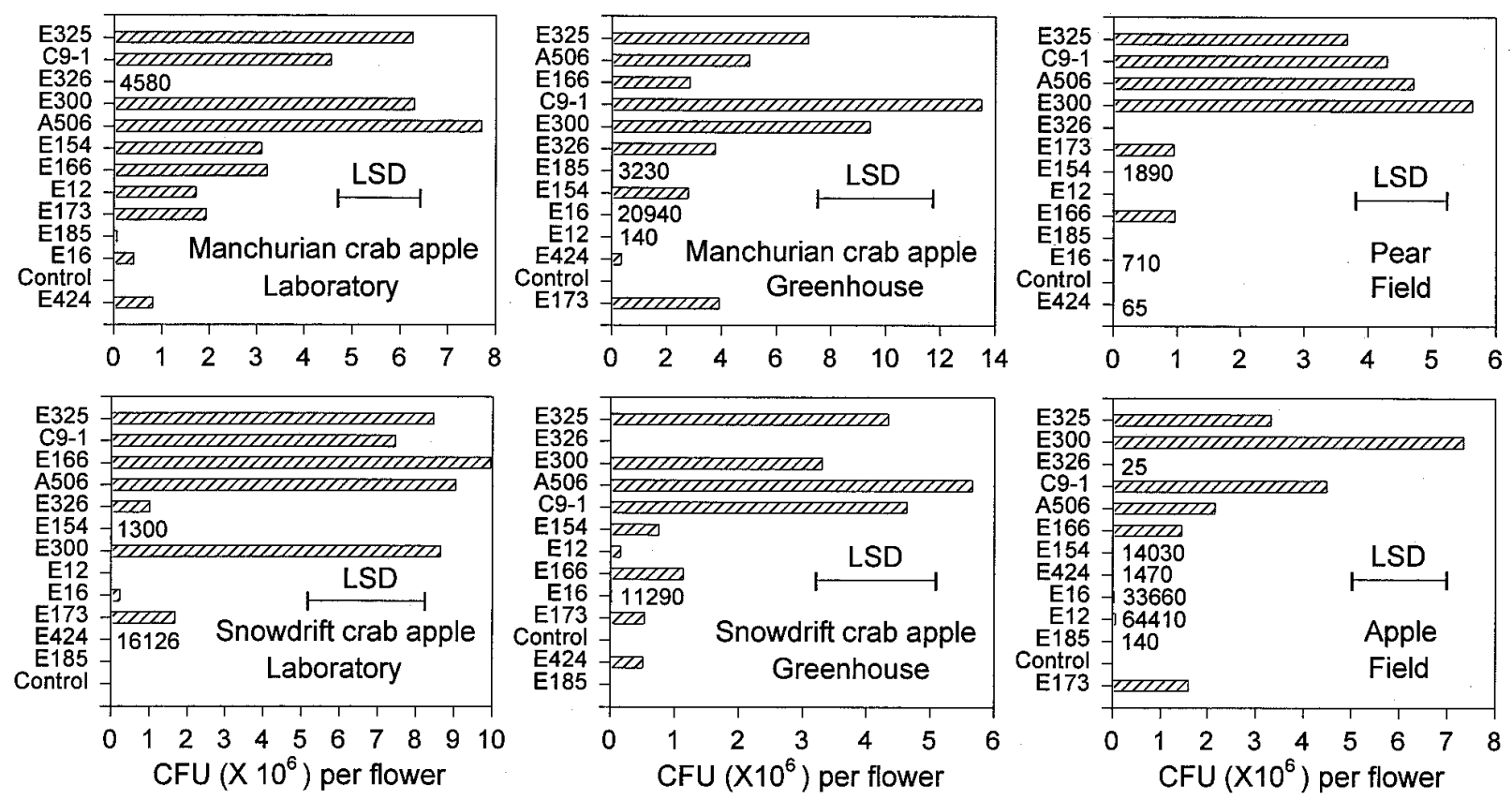

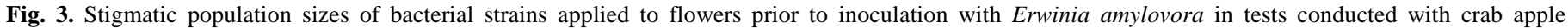

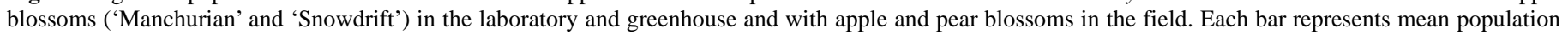

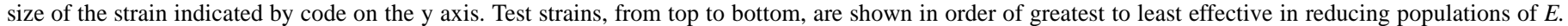
amylovora (as in Fig. 2). Line indicates least significant difference at $P \leq 0.05$. 
Effect of antagonists on disease development in detached blossoms. When detached flowers were maintained in a $10 \%$ sucrose solution, the size of bacterial populations supported on stigmas was similar to that previously determined for stigmas of flowers in $25 \%$ sucrose. With $10 \%$ sucrose, as compared with the higher concentration, stigmas remained green and healthy appearing for about the same period (5 to 6 days), but petals were retained for a shorter period ( 2 to 3 days). Population data were analyzed as a factorial experiment with three treatments and two sampling dates (Fig. 4). Population sizes on stigmas and hypanthia were analyzed separately. For Ea153 populations, an interaction was shown between treatment and sampling date (before or after flower wetting) for stigmas and hypanthia $(P \leq 0.05)$; however, this was not observed for antagonist populations on these flower parts. On each sampling date, both strains C9-1 and A506 were shown to suppress stigmatic populations of Ea153 ( $P \leq 0.05)$; before wetting, C9-1 was more effective than A506, but, after wetting, it was less effective than A506 (Fig. 4A). On the hypanthia of control flowers, the mean log population size of Ea153 increased from 2.08 before wetting to 6.46 after wetting (Fig. 4B). Before wetting, C9-1 and A506 equally suppressed Ea153 on the hypanthia; after wetting, only C9-1 significantly suppressed Ea153 on this flower part. Population sizes of the two antagonists on stigmas did not differ before or after wetting (Fig. 4C); however,
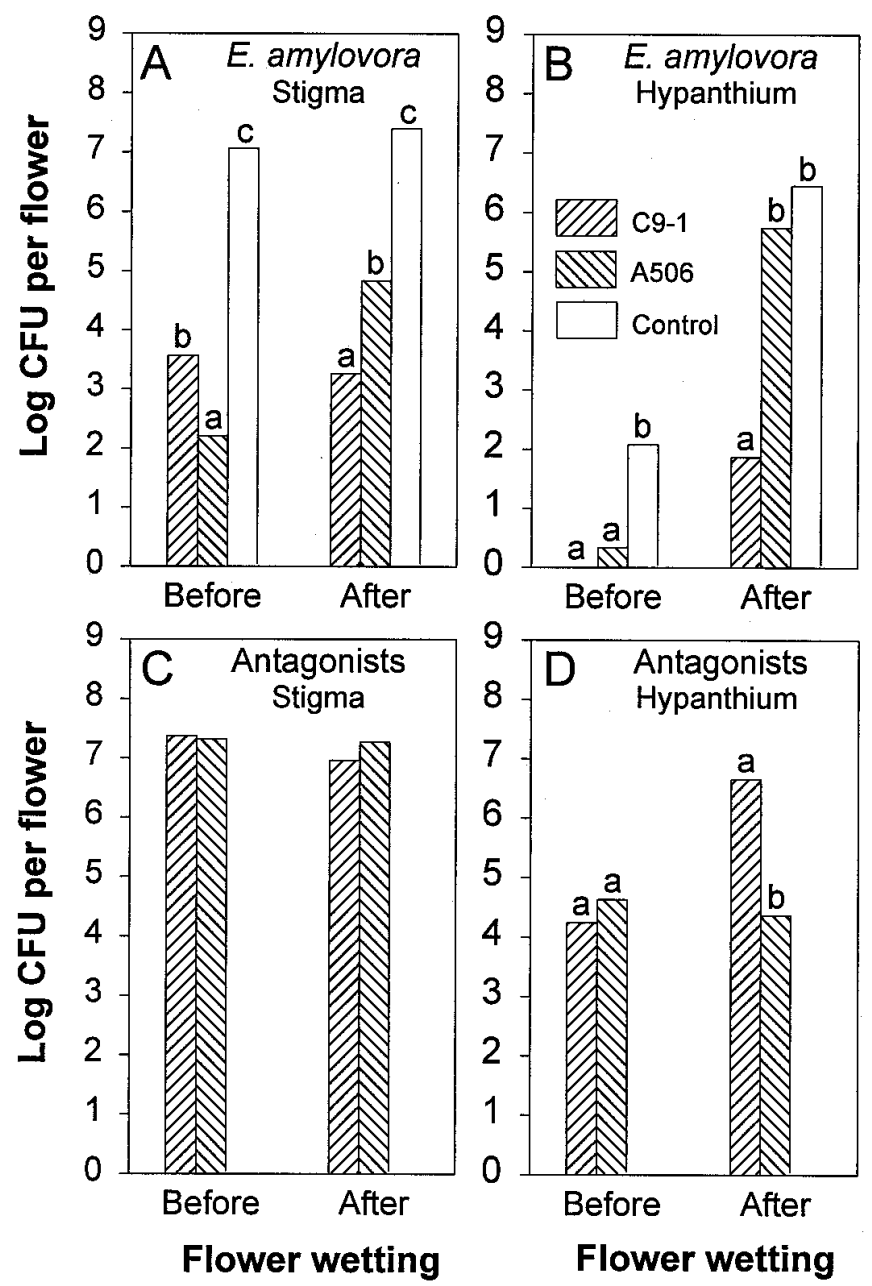

Fig. 4. Population sizes of $\mathbf{A}$ and B, Erwinia amylovora; and $\mathbf{C}$ and D, E. herbicola (C9-1) and Pseudomonas fluorescens (A506) on A and C, stigmas and $\mathbf{B}$ and D, hypanthia of detached blossoms of 'Manchurian' crab apple blossoms before and after a 24-h wetting period. Each bar represents a mean population size per flower. Means for the same sampling time (before or after wetting) with the same letter are not different according to the least significant difference test $(P \leq 0.05)$. after wetting, the population size of C9-1 on the hypanthia was greater than that of A506 (Fig. 4D).

In each of the two trials, flowers treated with $\mathrm{C} 9-1$ had lower disease ratings than those treated with A506 $(P \leq 0.05)$, and both antagonists were shown to reduce disease severity. When data were combined, mean disease ratings for C9-1, A506, and Ea153 alone (control) were $0.18,1.48$, and 3.35 , respectively; overall disease incidence was 10,50 , and $87.5 \%$, respectively.

\section{DISCUSSION}

The above tests indicate that the evaluation of microorganisms as biocontrol agents on flowers of crab apple blossoms in the laboratory or greenhouse can be used to predict how bacteria will affect E. amylovora on flowers of pear and apple in field environments. Unlike apple and pear, crab apple trees flower profusely on 1-year-old wood and were easily manipulated so that flowers were produced year-round. The increase in flower availability and the development of procedures for conducting tests with flowers in controlled laboratory environments are important steps that will accelerate research on biological control of fire blight.

Strains of E. herbicola and P. fluorescens were used to test the validity of crab apple as a model for fire blight biocontrol studies, since these bacteria have been studied extensively for use in the control of fire blight. Investigations involving the application of $E$. herbicola to pear or apple have been conducted for many years $(4,5$, 16). More recently, $P$. fluorescens strain A506 has been tested alone on blossoms of pome fruit trees $(10,13,25,31)$ or in combination with E. herbicola, either strain C9-1 $(11,19,20)$ or strain Eh252 (25).

At the constant temperature of $24^{\circ} \mathrm{C}$, bacterial populations on stigmas of detached crab apple blossoms increased rapidly and, by $24 \mathrm{~h}$, reached maximum or near-maximum levels of between $10^{6}$ and $10^{7} \mathrm{CFU}$ per flower (Fig. 1). Although this was generally not observed in studies with pear, apple, and hawthorn conducted in field or greenhouse environments at comparably lower temperatures, stigmatic populations of bacteria in these other settings often did eventually exceed $10^{6} \mathrm{CFU}$ per flower $(20,25,27,30,31)$.

At $72 \mathrm{~h}$ after inoculation of crab apple stigmas with antagonist strains A506 and C9-1, neither strain was shown to negatively effect the growth of the other (Fig. 1). This is consistent with field studies in which A506 and C9-1 were applied to pear (19), or A506 and the Eh252 strain of E. herbicola were applied to apple or Asian pear (25). Also, in the current and in previous studies $(30,31)$, populations of E. herbicola or A506 were not affected negatively by the later inoculation with $E$. amylovora.

Stigmatic populations of strain Ea153, whether applied in suspension at $10^{7}$ or $10^{8} \mathrm{CFU} / \mathrm{ml}$, had a rate of increase and a maximum comparable to that of the antagonists applied at $10^{8} \mathrm{CFU} / \mathrm{ml}$ (Fig. 1). Populations of E. amylovora on the detached crab apple flowers with and without antagonists were similar to those in studies with pear flowers preinoculated with A506 in a greenhouse (31) and flowers on hawthorn branches preinoculated with $E$. herbicola strain HL9N13 in a growth chamber (30). Although the effect of mixed versus individual antagonists on stigmatic populations of $E$. amylovora has not been reported before in detail, the results with crab apple were compatible with pear and apple field studies indicating that mixtures of A506 and E. herbicola (Eh252 or C9-1) were no more effective than either antagonist alone in reducing the incidence of fire blight $(19,25)$. Antagonist mixtures have, however, resulted in a greater proportion of blossoms being colonized by at least one antagonist (19) and, thus, may provide more consistent disease control over a wide range of conditions (24).

The relative effects of 12 bacterial strains on colonization of $E$. amylovora on flower stigmas were similar for crab apple blossoms in the laboratory or greenhouse, and for pear and apple blossoms in the field (Fig. 2), despite environmental differences and flowerto-flower variability. Strains that were most effective against Ea153 tended to be present in the highest populations (Fig. 3). This cor- 
responds with the view that microbial antagonists affect colonization of E. amylovora on the stigma through preemptive or competitive exclusion $(6,22,27,30,31)$. Some of the antagonists may also have produced antibiotics inhibitory to E. amylovora, as reported for E. herbicola C9-1 (9). E. herbicola strain E325, which always ranked first as an antagonist of Ea153, was likewise found to produce, in culture, extracellular metabolites inhibitory to the pathogen (P. L. Pusey, unpublished data). Although the relationship between stigmatic populations of E. amylovora and disease incidence may not be perfect (24), the ability of an antagonist to colonize the stigma and to reduce stigmatic populations of E. amylovora is of primary importance, particularly under dry conditions typical of the western United States $(22,27,30,31)$. With this characteristic, an antagonist presence will be maintained and pathogen inoculum levels will be held to a minimum during dry periods before conditions become favorable for disease development.

The laboratory subjection of flowers to a wetting period simulated field conditions conducive for blossom blight and provided further information that may be related to the overall efficacy of antagonists as biocontrol agents against fire blight. Wetting facilitates pathogen spread to infection sites in the hypanthium (22); thus, the hypanthium may be considered as a secondary line of defense against pathogen invasion. Prior to wetting, C9-1 was less effective than A506 against Ea153 on the stigma; however, after wetting, C9-1 was shown to be more effective than A506 in suppressing Ea153 on the hypanthium and in reducing disease severity and incidence. An explanation of this will have to await further research. Possibly, the increase in wetness caused an increase in C9-1 antibiotic production or activity. Also, according to other studies (P. L. Pusey, unpublished data), C9-1 has a greater tolerance than A506 to the relatively high sugar concentrations (thus, low osmotic potentials) frequently existent in the hypanthium, where nectar is present. Although disease data in the current study are not sufficient to assess the predictiveness of the crab apple model as it pertains to actual disease control in the field, the fact that biological control of blossom blight was successfully demonstrated in the laboratory may be significant. This opens the possibility for laboratory research that goes beyond the study of microbial interactions on flower surfaces to more in-depth investigations of microbeplant interactions.

The two crab apple cultivars, Manchurian and Snowdrift, were somewhat different with regard to flower production, flower morphology, and their usefulness in fire blight biocontrol studies. The following general observations were made. When dormant trees were received from the nurseries, 'Manchurian' trees had more lateral branches; thus, more flower buds than 'Snowdrift' trees. However, 'Snowdrift' usually produced more flowers in response to techniques used to induce a second bloom. Individual flowers of 'Manchurian' trees had stigmas that were in a tight cluster as compared with 'Snowdrift' stigmas, which were spread out; because of this difference, 'Manchurian' flowers were easier to inoculate so that all stigmas were colonized by bacteria, but more difficult to dry since water became entrapped between the styles. Bacterial population sizes supported on the two flower types were about the same. The development of infection leading to the expression of blossom blight symptoms was more easily demonstrated with detached flowers of 'Manchurian' than with those of 'Snowdrift', for unknown reasons. Preliminary trials (P. L. Pusey, unpublished data) indicated that disease occurred when the sucrose concentration in holding vials was reduced from 25 to $10 \%$. Presumably, this affected host solute potential, which consequently increased host susceptibility (21), but appeared not to affect bacterial populations on stigmas.

In conclusion, crab apple could serve as a useful model for yearround studies on biological control of the blossom blight phase of fire blight. It may permit studies not feasible during the normal bloom period because of limited time availability or uncontrolled conditions in field environments. Possible applications include labo- ratory screening of microbial strains or strain combinations for potential use in biocontrol, based on reduction of stigmatic populations of E. amylovora and reduction of disease development. Promising selections could later be tested on blossoms of intact crab apple plants in controlled-environment or greenhouse facilities before being advanced to field trials with apple and pear. In addition, employment of the crab apple model could extend to other fire blight research including studies relating to the efficacy of natural or synthetic chemicals, compatibility between microbial biocontrol agents and chemical agents, blossom blight etiology, pathogen virulence, and disease prediction models.

\section{ACKNOWLEDGMENTS}

This research was supported, in part, by the Washington State Tree Fruit Research Commission. Crab apple trees were donated by Van Well Nursery (Wenatchee, WA) and Cameron Nursery (Eltopia, WA). I thank J. Duffy, B. Blaisdell, and B. Steady for their valuable technical assistance.

\section{LITERATURE CITED}

1. Aldwinckle, H. S., and Beer, S. V. 1979. Fire blight and its control. Hortic. Rev. 1:423-474.

2. Ark, P. A., and Hunt, M. L. 1941. Saprophytes antagonistic to phytopathogenic and other microorganisms. Science 93:354-355.

3. Beer, S. V., and Rundle, J. R. 1983. Suppression of Erwinia amylovora by Erwinia herbicola in immature pear fruits. (Abstr.) Phytopathology 73:1346.

4. Beer, S. V., Rundle, J. R., and Wodzinski, R. S. 1984. Recent progress in the development of biological control for fire blight-A review. Acta Hortic. 151:195-201.

5. Epton, H. A. S., Wilson, M., Nicholson, S. L., and Sigee, D. C. 1994. Biological control of Erwinia amylovora with Erwinia herbicola. Pages 335-352 in: Ecology of Plant Pathogens. J. P. Blakeman and B. Williamson, eds. CAB International, Wallingford, United Kingdom.

6. Hattingh, M. J., Beer, S. V., and Lawson, E. W. 1986. Scanning electron microscopy of apple blossoms colonized by Erwinia amylovora and E. herbicola. Phytopathology 76:900-904.

7. Isenbeck, M., and Schulz, F. A. 1985. Biological control of fire blight (Erwinia amylovora [Burr.] Winslow et al.) on ornamentals: I. Control of the pathogen by antagonistic bacteria. Phytopathol. Z. 113:324-333.

8. Ishimaru, C., and Klos, E. J. 1984. New medium for detecting Erwinia amylovora and its use in epidemiological studies. Phytopathology 74: 1342-1345.

9. Ishimaru, C. A., Klos, E. J., and Brubaker, R. R. 1988. Multiple antibiotic production by Erwinia herbicola. Phytopathology 78:746-750.

10. Johnson, K. B., Stockwell, V. O., Burgett, D. M., Sugar, D., and Loper, J. E. 1993. Dispersal of Erwinia amylovora and Pseudomonas fluorescens by honey bees from hives to apple and pear blossoms. Phytopathology $83: 478-484$

11. Johnson, K. B., Stockwell, V. O., McLaughlin, R. J., Sugar, D., Loper, J. E., and Roberts, R. G. 1993. Effect of antagonistic bacteria on establishment of honey bee-dispersed Erwinia amylovora in pear blossoms and on fire blight control. Phytopathology 83:995-1002.

12. King, E. O., Ward, M. K., and Raney, D. E. 1954. Two simple media for the demonstration of pyocyanin and fluorescin. J. Lab. Clin. Med. 44: 301-307.

13. Lindow, S. E. 1984. Integrated control and role of antibiosis in biological control of fire blight and frost injury. Pages 83-115 in: Biological Control on the Phylloplane. C. Windels and S. E. Lindow, eds. The American Phytopathological Society, St. Paul, MN.

14. Lindow, S. E., McGourty, G., and Elkins, R. 1996. Interactions of antibiotics with Pseudomonas fluorescens strain A506 in the control of fire blight and frost injury to pear. Phytopathology 86:841-848.

15. Loper, J. E., Henkels, M. D., Roberts, R. G., Grove, G. G., Willet, M. J., and Smith, T. J. 1991. Evaluation of streptomycin, oxytetracycline, and copper resistance of Erwinia amylovora isolated from pear orchards in Washington state. Plant Dis. 75:287-290.

16. McIntyre, J. L., Kuc, J., and Williams, E. B. 1973. Protection of pear against fire blight by bacteria and bacterial sonicates. Phytopathology 63:872-877.

17. McManus, P. S., and Jones, A. L. 1994. Epidemiology and genetic analysis of streptomycin-resistant Erwinia amylovora from Michigan and evaluation of oxytetracycline for control. Phytopathology 84:627-633.

18. Pusey, P. L. 1996. Crab apple blossoms as a model system for fire blight biocontrol research. Acta Hortic. 411:289-293.

19. Stockwell, V. O., Johnson, K. B., and Loper, J. E. 1992. Establishment of 
bacterial antagonists on blossoms of pear. (Abstr.) Phytopathology 82:1128.

20. Stockwell, V. O., Johnson, K. B., and Loper, J. E. 1996. Compatibility of bacterial antagonists of Erwinia amylovora with antibiotics used to control fire blight. Phytopathology 86:834-840.

21. Suleman, P., and Steiner, P. W. 1994. Relationship between sorbitol and solute potential in apple shoots relative to fire blight symptom development after infection by Erwinia amylovora. Phytopathology 84:1244-1250.

22. Thomson, S. V. 1986. The role of the stigma in fire blight infections. Phytopathology 76:476-482.

23. van der Zwet, T., and Keil, H. L. 1979. Fire blight: A bacterial disease of rosaceous plants. Agric. Handb. 510. U.S. Dep. Agric., Sci. Educ. Admin., Washington, DC.

24. Vanneste, J. L. 1996. Honey bees and epiphytic bacteria to control fire blight, a bacterial disease of apple and pear. Biocontrol News Information $17: 67 \mathrm{~N}-78 \mathrm{~N}$.

25. Vanneste, J. L., and Yu, J. 1996. Biological control of fire blight using Erwinia herbicola Eh252 and Pseudomonas fluorescens A506 separately or in combination. Acta Hortic. 411:351-353.
26. Vanneste, J. L., Yu, J., Harper, G. E., and Perry, J. H. 1996. Plugs of immature pear fruit to assess the virulence of Erwinia amylovora and to study in the laboratory the interaction between biological control agents and the fire blight pathogen. Acta Hortic. 411:303-305.

27. Wilson, M., Epton, H. A. S., and Sigee, D. C. 1989. Erwinia amylovora infection of hawthorn blossom: II. The stigma. J. Phytopathol. 127:15-28.

28. Wilson, M., Epton, H. A. S., and Sigee, D. C. 1990. Biological control of fire blight of hawthorn (Crataegus monogyna) with Erwinia herbicola under protected conditions. Plant Pathol. 39:301-308.

29. Wilson, M., Epton, H. A. S., and Sigee, D. C. 1992. Biological control of fire blight of hawthorn (Crataegus monogyna) with fluorescent Pseudomonas spp. under protected conditions. J. Phytopathol. 136:16-26.

30. Wilson, M., Epton, H. A. S., and Sigee, D. C. 1992. Interactions between Erwinia herbicola and E. amylovora on the stigma of hawthorn blossoms. Phytopathology 82:914-918.

31. Wilson, M., and Lindow, S. E. 1993. Interactions between the biological control agent Pseudomonas fluorescens A506 and Erwinia amylovora in pear blossom. Phytopathology 83:117-123. 